\title{
A new species of Echinolittorina Habe, 1956 (Gastropoda: Littorinidae) from the Quaternary of Chile
}

\author{
Juan Francisco Araya and David G. Reid
}

\begin{abstract}
We describe a new fossil littorinid species, Echinolittorina nielseni sp. nov., from the Quaternary Caldera Strata, Región de Atacama, northern Chile. Fossils of littorinids are globally rare because of their high-intertidal habitat on rocky shores. The new species has a large, broad shell with strong spiral ribs and an angled periphery, differing from the two living littorinids currently found along the coasts of mainland Chile and from all the extant species distributed in the southeastern Pacific. In comparison with the living Chilean Echinolittorina peruviana, the new species shows stronger ribs and more inflated whorls, but they share an unusual detail in the irregular arrangement of spiral sculpture. We hypothesize that the new species may be ancestral or sister to $E$. peruviana and discuss the adaptive significance of shell sculpture.
\end{abstract}

Juan Francisco Araya. Departamento de Geología, Universidad de Atacama, Copayapu 485, Copiapó, Región de Atacama, Chile and Programa de Doctorado en Sistemática y Biodiversidad, Universidad de Concepción, Concepción, Chile. jfaraya@u.uchile.cl

author: zoobank.org/Authors/443B4F42-FB13-42A6-B92B-1B0F835698A9

orcid.org/0000-0002-4087-964

David G. Reid. Mollusca Research Group, Department of Life Sciences, The Natural History Museum, London SW7 5BD, United Kingdom.d.reid@nhm.ac.uk

Keywords: Quaternary; Pleistocene; SE Pacific Ocean; Littoraria; new species

Submission: 19 September 2015 Acceptance: 29 January 2016

\section{INTRODUCTION}

The shallow-water marine molluscs living in northern Chile are relatively well known, having been the subject of regional faunistic studies (e.g., Marincovich, 1973; Guzman et al., 1998; Ashton, 2007; Araya and Araya, 2015), while some members of widespread genera have been included in monographic revisions (e.g., McLean, 1984; Reid, 2002; Geiger, 2012). Nevertheless, new living spe- cies continue to be discovered in the area, particularly in the Región de Atacama (Osorio, 2012; Araya, 2013). In comparison, there have been fewer studies of fossil molluscs from coastal northern Chile. Many are old works dealing with the marine species from the Miocene to Pliocene Bahia Inglesa Formation, with a characteristic temperate to tropical fauna (Philippi, 1887; Möricke, 1896; Herm, 1969). Quaternary species from

zoobank.org/22386A7C-0400-4B21-A17F-9979F3DE6BBB

Araya, Juan Francisco and Reid, David G. 2016. A new species of Echinolittorina Habe, 1956 (Gastropoda: Littorinidae) from the Quaternary of Chile. Palaeontologia Electronica 19.1.8A: 1-8

palaeo-electronica.org/content/2016/1426-a-new-echinolittorina

Copyright: February 2016 Paleontological Society 
around Caldera were first mentioned by Herm (1969) and have recently been the subject of renewed study (Guzmán et al., 2000; Guicharrousse et al., 2015).

In contrast to the older fossils from northern Chile, those of the Quaternary Caldera Strata include mainly warm-temperate species, of which a high proportion is extant on the nearby coasts. For example, the molluscan assemblage at the locality described here consists of 40 species, all but two of which are still living, including the bivalve Mulinia edulis (King and Broderip, 1832), the gastropod Aeneator aff. fontainei (d'Orbigny, 1839) and the chiton Acanthopleura echinata (Barnes, 1824). This assemblage indicates a coastal, shallowwater environment with sandy pockets and sparse rocky outcrops (cf. Araya, 2013; Araya and Araya, 2015). These species have been extensively reported from Quaternary deposits, while a few of them also have Miocene records (Nielsen, 2013); however, the extant muricid gastropod Concholepas concholepas (Bruguière, 1789) and the scallop Argopecten purpuratus (Lamarck, 1819) indicate that the assemblage is no older than the Pleistocene (Guzmán et al., 2000; Marquardt et al., 2000).

The systematics and phylogeny of the family Littorinidae have been as thoroughly investigated as those of any marine gastropod group (Reid et al., 2012, and references therein) and they have become a model system for the study of diversification in the marine realm. In a dated molecular phylogeny, most of the living littorinids are estimated to have originated in the Oligocene to Miocene, although $46 \%$ of the 60 extant Echinolittorina species diverged more recently (Reid et al., 2012). Littorinidae are represented in the living fauna of northern Chile by two common species, Echinolittorina peruviana (Lamarck, 1822) and Austrolittorina araucana (d'Orbigny, 1840) (Reid, 2002; but see Reid et al., 2012 for current generic assignments). The majority of littorinids, including these two, are typically found in abundance at high intertidal levels on wave-exposed rocky shores, where the potential for fossil preservation is generally low. Therefore, fossil records of the family are globally extremely scarce (review by Reid, 1989). As expected, the fossil record of these two species in Chile is very limited, with a single Pleistocene record (not figured) for Echinolittorina peruviana at Caleta Patillos $\left(20^{\circ} 45^{\prime} \mathrm{S}\right.$; $\left.70^{\circ} 12^{\prime} \mathrm{W}\right)$, in northern Chile (Rivadeneira and Carmona, 2008). For all these reasons, the discovery of a distinctive new species of Littorinidae in the Quaternary Caldera Strata is of interest and is reported here.

\section{MATERIALS AND METHODS}

The type locality of the new littorinid species is a small, low cliff to the east of El Morro Hill, one of a series of low terraces $10 \mathrm{~km}$ south of Caldera, Región de Atacama, northern Chile (Figure 1). It consists of a semi-consolidated and fossiliferous sedimentary formation composed of littoral marine coquinas, sandstone, cherts, phosphorites and diatomites (Marquardt et al., 2000; Godoy et al., 2003). The upper layer, of variable thickness and which contains the new species, is part of the Caldera Strata and the presence of Concholepas concholepas and Argopecten purpuratus indicates no more than a Pleistocene age (Guzmán et al., 2000; Marquardt et al., 2000). As described above, the molluscan assemblage is consistent with a shallow coastal environment of sand and sparse rocky outcrops (cf. Araya, 2013; Araya and Araya, 2015). No other littorinid taxa were present in the assemblage. The specific location where the new species was found was protected from the open ocean by the El Morro Hill, a massive $2 \times 4 \mathrm{~km}$ outcrop aligned almost $\mathrm{N}-\mathrm{S}$, parallel to the coast, and up to 323 m high (Herm, 1969; Godoy et al., 2003).

Sampling was carried out in January 2012 at an eroded cliff. Bulk samples were obtained from the upper $2 \mathrm{~cm}$ of the sediment and further sieved, with some specimens picked out by hand. The specimens described here have been deposited in the collections of the Museo Nacional de Historia Natural, Santiago, Chile (SGO.PI), in the Natural History Museum, London, U.K. (NHMUK), and in the Museo Paleontológico de Caldera, Caldera, Chile (MPCCL). For the morphological descriptions, the shell height parallel to the axis of coiling $(\mathrm{H})$, breadth $(\mathrm{B})$ perpendicular to $\mathrm{H}$ and maximum length of aperture (LA) were measured with Vernier callipers $( \pm 0.1 \mathrm{~mm})$.

\section{SYSTEMATIC PALAEONTOLOGY}

Phylum MOLLUSCA Linnaeus, 1758 Class GASTROPODA Cuvier, 1795

Subclass CAENOGASTROPODA Cox, 1960

Family LITTORINIDAE Anonymous, 1834

Genus ECHINOLITTORINA Habe, 1956

Type species. Litorina tuberculata Menke, 1828, by original designation.

Distribution. Worldwide tropical and warm temperate seas (Reid et al., 2012). Eocene to Recent.

Echinolittorina nielseni sp. nov.

Figure 2.1-8

zoobank.org/DD2906C5-7FE3-4DFF-9C50-5A2471AADDA3 


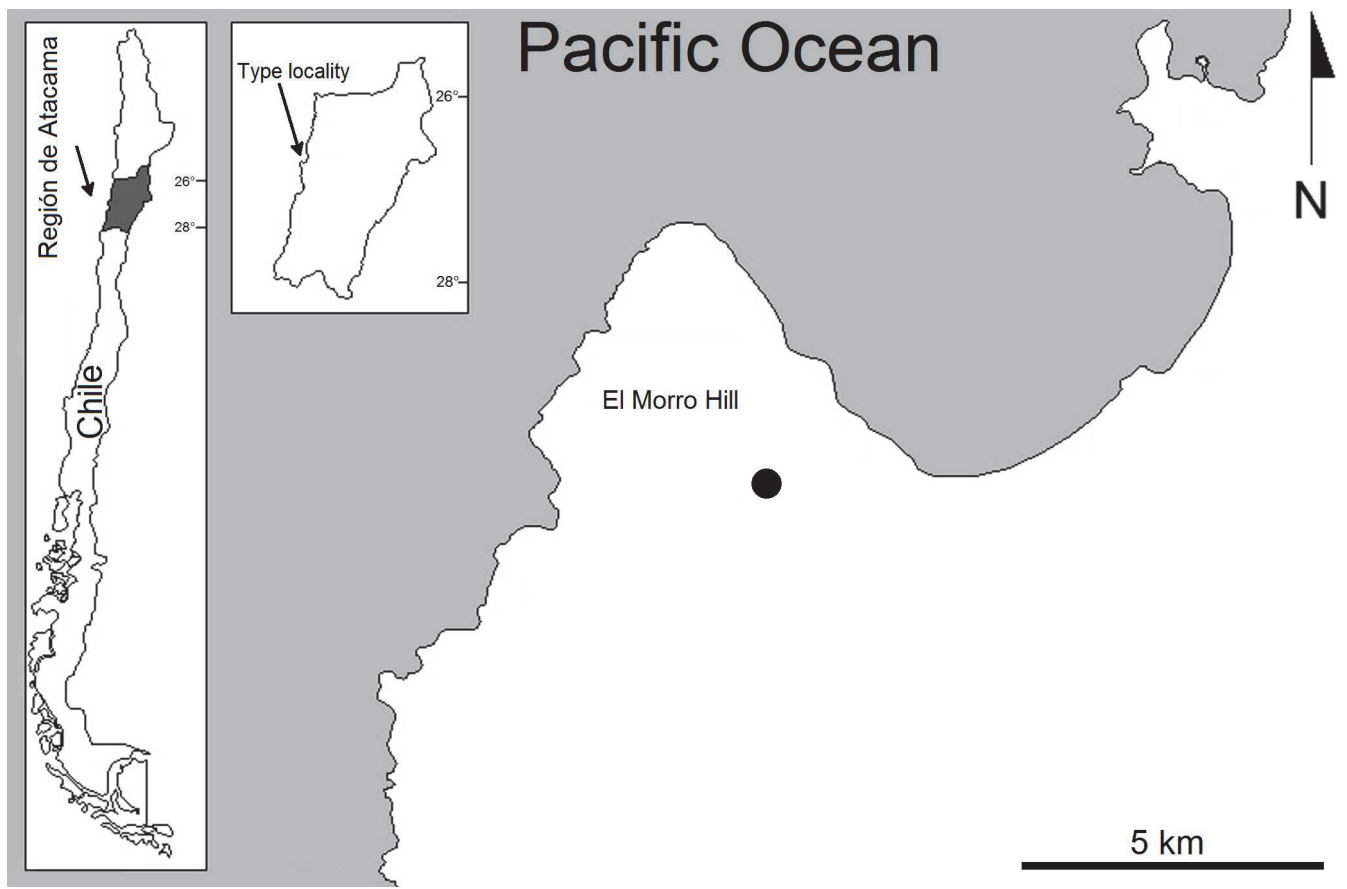

FIGURE 1. Map of the study region showing the type locality of Echinolittorina nielseni sp. nov. in Caldera, northern Chile.

\section{v. 2015 Echinolittorina n. sp.; Araya and Reid, p. 85 , figs $1 . \mathrm{A}-\mathrm{H}$.}

Diagnosis. Large, broad Echinolittorina with rounded whorls, concave spire profile, 7-9 strong spiral ribs at and above angled periphery.

Description. Shell large $(H=15.7-22.2 \mathrm{~mm})$. Shape high turbinate $(H / B=1.29-1.44 ; H / L A=$ 1.54-1.83); spire whorls well rounded, suture distinct; spire profile concave near apex; periphery of last whorl slightly but distinctly angled; rarely a slight angulation at shoulder (Figure 2.6-7). Columella straight, moderately broad, slightly hollowed and pinched at base; no eroded parietal area. Sculpture of 7-9 low, broad, rounded, spiral ribs above periphery (including the strongest rib at periphery), becoming less distinct near suture; ribs of unequal width and prominence, separated by narrow grooves or incised lines. Base with 6-8 finer ribs. No spiral microstriae visible. A trace of colour is preserved on one specimen, showing a pale spiral band on the base (Figure 2.4). None of the specimens showed fluorescence under ultraviolet light, which might have revealed original colour patterns.

Type material. Holotype: SGO.PI 23.100 (Figure 2.1-2); Paratypes NHMUKPAL PI TG 2676926775 (Figure 2.3-8, seven specimens), MPCCL 14012016 (fifteen specimens). All the material col- lected at type locality by J. F. Araya, January 15, 2012.

Type locality. Eroded cliff east of El Morro Hill, about $10 \mathrm{~km}$ south of Caldera, Región de Atacama,

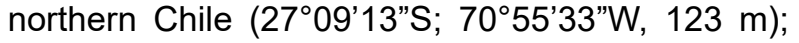
Pleistocene.

Etymology. The name of the species honours our friend Sven Nielsen (Universidad Austral de Chile, Valdivia, Chile) for his extensive research on Chilean fossil molluscs.

Remarks. These relatively large, thick, spirallysculptured shells with an entire aperture containing a basal white band, and lacking an umbilicus, unquestionably belong to the subfamily Littorininae (reviewed by Reid, 1989) and can be compared with members of its living genera. Superficially, the shells resemble members of the littorinid genus Littoraria; this assignment is suggested by the strong spiral sculpture, the enlarged peripheral rib that gives an angled profile to the final whorl, and the somewhat short and wide columella. In the recent fauna six Littoraria species occur on the Pacific mainland coast of Central and South America, but all have a tropical distribution and five are almost entirely restricted to mangrove and halophyticgrass habitats. The one rocky-shore species (Littoraria pintado [Wood, 1828]; see Reid, 1999a; Reid et al., 2010) can be discounted because it is smooth-shelled and relatively narrow with a straight spire. The most southerly records of living 


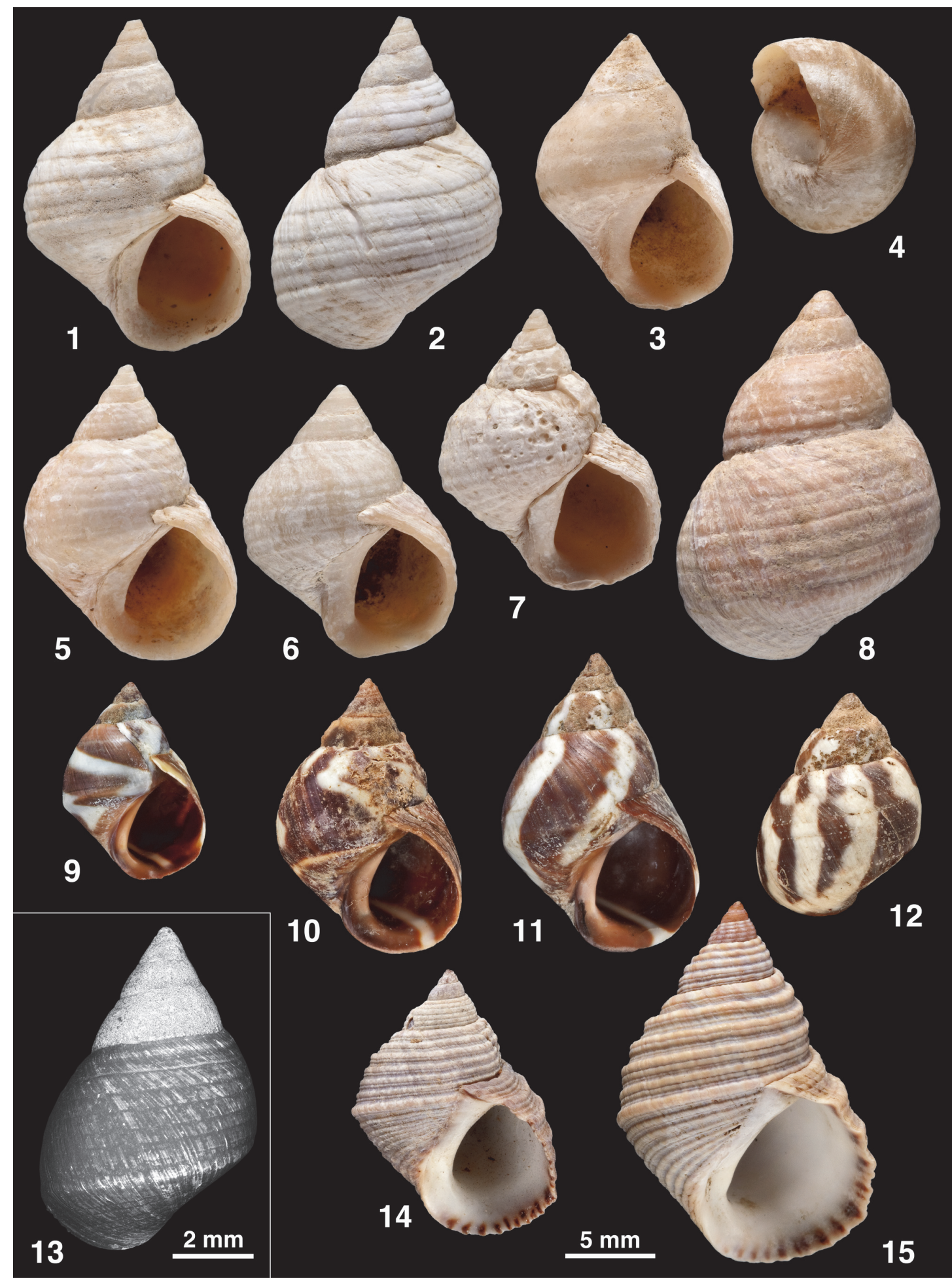

FIGURE 2. Shells of Echinolittorina nielseni sp. nov. and of two extant littorinids: 1-8, Echinolittorina nielseni sp. nov., SGO.PI 23.100 (holotype) (1 and 2), NHMUK PAL PI TG 26769 (paratype) (3 and 4), NHMUK PAL PI TG 2677026773 (paratypes) (5-8); 9-13, Echinolittorina peruviana (Lamarck, 1822), NHMUK acc. no. 2176 (9 and 12), NHMUK 20001268 (10), NHMUK 20001269 (11), NHMUK unnumbered (13); and 14 and 15, Littoraria varia (Sowerby, 1832), NHMUK 1850.4.23.273 (14) and NHMUK 1850.4.23.274 (15). 13 is a scanning electron micrograph showing shell sculpture. 2, 8, 12, 13 are abapertural views and 4 is a basal view; others are apertural views. Collection localities: Chile $($ El Morro, Atacama) $=1-8$, Chile $($ Valparaíso $)=9$ and 12, Perú (Lagunilla Beach, Paracas $)=13$, Panama $=14$ and 15; others are unknown. 
Littoraria species are between $3^{\circ}$ and $5^{\circ} \mathrm{S}$ in northernmost Peru (Reid, 1999a). Since the present fossil sample is from $27^{\circ} \mathrm{S}$ in northern Chile and accompanied by a fauna of temperate, rocky-shore gastropods, their identification as a Littoraria species associated with mangrove trees would be extremely surprising. Of the living Littoraria species, the new species most closely resembles Littoraria varia (Sowerby, 1832) (see Reid, 1999a) (Figure 2.14-15). However, close comparison shows that the sculpture of $L$. varia is stronger, the primary spiral ribs more equal in width, and that they are separated by wide grooves with secondary ribs and fine spiral microstriae, quite unlike the rounded ribs separated by grooves that are little more than incised lines in the new species. The peripheral angle is marked by a strong rib in $L$. varia, and there is sometimes a slight angle at the shoulder as well (Figure 2.14), which are points of similarity with the fossils (compare with Figure 2.67 ). One of the fossil shells bears a spiral white band on the base (Figure 2.4); this band is weakly present (and then only within the aperture) in only three of the 39 living Littoraria species (Reid, 1999b), but is present in a variety of other littorinid genera (Reid, 1989), including all members of the genus Echinolittorina (Reid, 2002, 2007, 2009, 2011). The sculptural details and presence of the white basal band exclude the present shells from Littoraria.

Turning to the modern rocky-shore fauna of the eastern Pacific Ocean, there are 18 littorinid species in the genera Echinolittorina and Austrolittorina (see Reid, 2002 for detailed descriptions and Reid et al., 2012 for current generic assignments based on molecular phylogeny). All have a basal white band visible within the aperture and often externally as well. None of the members of Echinolittorina in the tropical eastern Pacific is similar to the new species, being smaller, narrower, usually with regular spiral grooves, and sometimes nodulose or umbilicate. Two of the three temperate littorinid species can also be discounted: Austrolittorina fernandezensis (Rosewater, 1970) is large (to $21 \mathrm{~mm}$ ), but macroscopically smooth, and is endemic to the Juan Fernández Archipelago, off central Chile; Austrolittorina araucana (d'Orbigny, 1840 ) is common in Chile, again macroscopically smooth, but does not exceed $13.8 \mathrm{~mm}$ in height. The only other living littorinid in the southeastern Pacific is Echinolittorina peruviana (Lamarck, 1822). This is a well-known species, common on temperate shores from northern Peru to southern Chile ( $5^{\circ} 05^{\prime} S$ to $41^{\circ} 49^{\prime} S$; Reid, 2002; Castillo and
Brown, 2010), where it is found in local assemblages that are much the same as that in which the fossil shells occurred. It too can reach a large size, up to $23.8 \mathrm{~mm}$ high. However, shells of $E$. peruviana are usually smooth, relatively elongate $(H / B=$ 1.31-1.88; H/LA = 1.46-1.93), the whorls are not swollen, the columella is long and the anterior apertural margin protrudes slightly (Figure 2.9-12) (Reid, 2002) - characters which at first appear to exclude close relationship with the new species. However, a very few shells of E. peruviana (13/884 $=1.4 \%$ of shells examined from throughout geographical range) show "1-4 (rarely 6-8) faint incised lines above periphery" (Reid, 2002: 147) (Figure 2.9,12-13). Sometimes, even in smooth shells, irregularities in the axial colour stripes show a periodicity similar to that of the incised spiral lines (compare Figure 2.11 and 2.12). The incised lines are shown more clearly in an SEM of a well-preserved juvenile shell (Figure 2.13). The spacing of the incised spiral lines in these rare shells of $E$. peruviana is not as regular as the "primary spiral grooves' of typical tropical Echinolittorina species (e.g., Reid, 2002), instead recalling the somewhat unequal ribs of the fossils. It is, therefore, proposed that $E$. nielseni sp. nov. is a member of Echinolittorina and is most closely related to E. peruviana.

\section{DISCUSSION}

Generic assignment of littorinid shells in the subfamily Littorininae, even of living species, can be difficult because shell colour pattern and shape are quite uniform across the subfamily, whereas sculpture is variable, but prone to homoplasy (Reid, 1989). Shells are, therefore, often an unreliable guide to affinity (even at generic level), so that the advent of systematic anatomical studies (Reid, 1989) and of molecular phylogenetics (e.g., Reid et al., 2012) have had profound effects on littorinid classification. Littorinids mainly inhabit wave-swept intertidal shores, and their fossils are consequently extremely rare (Reid, 1989). These rare fossils are seldom well preserved and their classification presents considerable difficulty. The 23 shells in this sample are not significantly damaged by erosion or abrasion, so their surface sculpture is clear, and there is even a trace of colour pattern on one specimen. While their generic placement in Echinolittorina is not immediately obvious (as discussed in detail above), our observations of sculptural details and the basal white band make a strong case.

To assess whether the fossil shells differ sufficiently from the living form to justify diagnosis as a separate species, it is necessary to consider their 
respective ranges of morphological variation. Only about $1.4 \%$ of living specimens of $E$. peruviana bear faint incised spiral lines and none show the strong, rounded spiral ribs of the fossil shells. The living shells have less rounded whorls and are usually more elongate than the fossils, although there is overlap in the range of the ratio H/B. There are also subtle differences in the shape of the aperture. It could be argued that, since the fossil shells originate from a single locality, they represent an isolated population of extreme variants of $E$. peruviana. However, all Echinolittorina species have planktotrophic development and their larvae are likely able to disperse for more than $1400 \mathrm{~km}$ in ocean currents (Williams and Reid, 2004). Isolation of a small local population, followed by genetic drift or selection, is not likely and there is no evidence for such effects in this genus. The type locality of the new species $\left(27^{\circ} \mathrm{S}\right)$ lies near the midpoint of the modern range of $E$. peruviana $\left(5-42^{\circ} S\right)$, so at least under current conditions the fossil locality is not near the edge of the range of the living species. Striking variation in shell sculpture on a small local scale does occur in some species of Echinolittorina, but is the result of ecophenotypic plasticity (Yeap et al., 2001; Reid, 2007). This usually takes the form of nodules and spiral striae in small individuals and spiral striae alone in large ones; the development of nodules is apparently connected with slow growth in unfavourable hot, dry microhabitats on horizontal rock surfaces. Reid (2002) examined 63 samples and over 800 shells of $E$. peruviana from throughout its range and reported no cases of localized variation consistent with ecophenotypic effects on shell sculpture. We, therefore, conclude that description of the new species is justified.

The great majority of Echinolittorina species bear strong spiral striae, spiral ribs or rows of nodules (Reid, 2002, 2007, 2009, 2011), as do most other members of the Littorininae (Reid, 1989). Outgroup comparison suggests, therefore, that the sculpture of $E$. nielseni is plesiomorphic. The only fossils of $E$. peruviana recorded from Chile were not figured (Rivadeneira and Carmona, 2008). With additional sampling of fossil shells it might be possible to address hypotheses such as whether $E$. nielseni is the sculptured ancestor of the smooth species E. peruviana, or whether the two are sister species. If the latter, then geographical separation can be predicted, because sister species of Echinolittorina are almost always allopatric, implying that geographical isolation is required for speciation (Williams and Reid, 2004). Strongly sculptured (both ribbed and nodulose) littorinid species tend to predominate in the tropics and at higher tidal levels on the shore (Vermeij, 1973). Furthermore, the one well-studied case of ecophenotypic plasticity in Echinolittorina (Yeap et al., 2001) suggested that strong sculpture might be functional in relation to convective heat loss. At present, smooth-shelled $E$. peruviana extends to higher latitudes than all but two of the 60 worldwide living Echinolittorina species (Williams and Reid, 2004; Reid et al., 2012). We, therefore, hypothesize that if E. peruviana and E. nielseni were once allopatric sister species, the latter may have had the more northerly (more tropical) distribution. Alternatively, anagenetic change from a sculptured ancestor to a smooth descendant species could suggest adaptation to a cooling climate. In the molecular phylogeny of Echinolittorina, no living species was identified as sister to $E$. peruviana; it was a basal member of an Eocene clade (Reid et al., 2012), indicating a long period of independent evolution or extinction of related species.

The assemblage of fossil molluscs at the present site indicates a coastal shallow-water environment. The abundant shell remains of the bivalve Mulinia edulis, which lives exclusively on open sandy beaches, and the presence of species of the gastropod genus Chlorostoma ( $C$. atrum [Lesson, 1830], C. luctuosa [d'Orbigny, 1841] and C. tridentata [Potiez and Michaud, 1838]), and of some polyplacophorans and limpets-known to live exclusively on rocky shores-points to a mixed area with rocky and sandy habitats, which at the time was protected from the open Pacific Ocean by the El Morro outcrop. With the exception of the new Echinolittorina described herein and one Cyclocardia species, all the molluscan taxa found at the site are currently represented in the living fauna of the area (Guicharrousse et al., 2015).

\section{ACKNOWLEDGEMENTS}

The authors are grateful to $S$. Nielsen (Universidad Austral de Chile, Valdivia, Chile) for his help with literature and information on related species; to the staff of the library of the Facultad de Ciencias and of the Departamento de Geología of the Universidad de Chile, in Santiago, Chile for their help with geological literature for the site; to M.E. Araya (Caldera, Chile) for her essential help in the field; to $\mathrm{H}$. Taylor (NHMUK) for taking the photographs; to M. Guicharrouse and G. Roa (MPCCL) for their help in preparing the map of Figure 1; and to A. Beu (GNS Science, Lower Hutt, New Zea- 
land) and an anonymous reviewer for corrections and suggestions that improved this work.

\section{REFERENCES}

Anonymous. 1834. Synopsis of the Contents of the British Museum. Edition 28. British Museum, London.

Araya, J.F. 2013. A new species of Aeneator Finlay, 1926 (Mollusca, Gastropoda, Buccinidae) from northern Chile, with comments on the genus and a key to the Chilean species. ZooKeys, 257:89-101.

Araya, J.F. and Araya, M.E. 2015. The shallow-water chitons (Mollusca, Polyplacophora) of Caldera, Region of Atacama, northern Chile. Zoosystematics and Evolution, 91:45-58.

Araya, J.F. and Reid, D.G. 2015. Una nueva especie de Echinolittorina (Mollusca: Gastropoda: Littorinidae) para el registro fósil de Chile, p. 85. In Moreno, K., Nielsen, S., Abarzúa, A., and Silva y Felipe Leiva, N. (eds.), Libro de Resúmenes IV Simposio de Paleontología, Valdivia, Chile. (In Spanish)

Ashton, T. 2007. A Field Guide to Molluscs of Northern Chile. S. I. Native Marine, [place of publication not stated].

Barnes, D.H. 1824. Description of five species of Chiton. American Journal of Science, 7(1):69-72.

Bruguière, J.G. 1789. Encyclopédie Méthodique. Histoire Naturelle des Vers. Tome premier [part 1]. Panckoucke, Paris. (In French)

Castillo, V.M. and Brown, D.I. 2010. Echinolittorina peruviana (Lamarck, 1822): antecedentes de la especie. Amici Molluscarum, 18:39-42. (In Spanish)

Cox, L.R. 1960. Thoughts on the classification of the Gastropoda. Proceedings of the Malacological Society of London, 33(6):239-261.

Cuvier, G. 1795. Second mémoire sur l'organisation et les rapports des animaux à sang blanc, dans lequel on traite de la structure des Mollusques et de leur division en ordre, lu à la société d'Histoire Naturelle de Paris, le 11 prairial an troisième [30 May 1795]. Magazin Encyclopédique, ou Journal des Sciences, des Lettres et des Arts, 1:433-449. (In French)

d'Orbigny, A. 1835-43. Voyage dans l'Amérique Méridionale, vol. 5, part 3 (Mollusques). P. Bertrand, Paris. (In French)

Geiger, D.L. 2012. Monograph of the Little Slit Shells, vols. 1 and 2. Santa Barbara Museum of Natural History, Santa Barbara.

Godoy, E., Marquardt, C., and Blanco, N. 2003. Carta Caldera, Región de Atacama. Carta Geológica de Chile, Serie Geología Básica, 76. Servicio Nacional de Geología y Minería, Santiago, Chile. (In Spanish)

Guicharrousse, M., Roa, G., Cortés, G., and Araya, J.F. 2015. La fauna de moluscos cuaternarios de Caldera, Región de Atacama, Chile, (page numbers unknown). In Comité Organizador XIV Congreso Geológico Chileno (ed.), Libro de Resúmenes XIV Congreso Geológico Chileno, La Serena, Chile. (In Spanish)
Guzmán, N., Marquardt, C., Ortlieb, L., and Frassinetti, D. 2000. La malacofauna neógena y cuaternaria del área de Caldera $\left(27^{\circ}-28^{\circ} \mathrm{S}\right)$ : especies y rangos bioestratigráficos, p. 476-481. In (editor unknown), Libro de Resúmenes IX Congreso Geológico Chileno, Puerto Varas, Chile. (In Spanish)

Habe, T. 1956. Notes on the systematic position of three American sea shells. Venus, 19: 95-100.

Herm, D. 1969. Marines Pliozän und Pleistozän in Nord und Mittel Chile unter besonderen Berücksichtigung der Entwicklung der Mollusken-Faunen. Zitteliana, 2:1-159. (In German)

King, P.P. and Broderip, W.J. 1832. Description of the Cirripedia, Conchifera and Mollusca in a collection formed by the officers of HMS Adventure and Beagle employed between the years 1826 and 1830 in surveying the southern coasts of South America, including the straits of Magellans and the coast of Tierra del Fuego. Zoological Journal, 5:332-349.

Lamarck, J-B.de. 1819. Histoire Naturelle des Animaux sans Vertèbres. Librairie Verdière, Paris. (In French)

Lamarck, J-B.de. 1822. Histoire Naturelle des Animaux sans Vertèbres. Tome septième. Published by the author. (In French)

Lesson, R.P. 1830-1831. Mollusques, Annelides et Vers. In Lesson, R.P., Gamot, P., and Guérlin-Méneville, F.E. Zoologie, 2(1). In Duperrey, L.I., 1825-1830, Voyage Autour du Monde, sur la Corvette de Sa Majesté, La Coquille, pendant les années 1822, 1823, 1824 et 1825, sous le commandement du capitaine Duperrey. A. Bertrand, Paris. (In French)

Linnaeus, C. 1758. Systema Naturae per Regna Tria Naturae. Tomus I. Editio decima, reformata. L. Salvii, Holmiae. (In Latin)

Marquardt, C., Blanco, N., Godoy, E., Lavenu, A., Ortlieb, L., Marchant, M., and Guzmán, N. 2000. Estratigrafía del Cenozoico Superior en el área de Caldera (26 45'-28 S), III Región de Atacama, p. 504508. In (editor unknown), Actas IX Congreso Geológico Chileno, Puerto Varas, Chile. (In Spanish)

McLean, J.H. 1984. Systematic of Fissurella in the Peruvian and Magellanic faunal provinces (Gastropoda: Prosobranchia). Bulletin of the Natural History Museum of Los Angeles County, 354:1-69.

Menke, K.T. 1828. Synopsis Methodica Molluscorum Generum Omnium et Specierum Earum, quae in Museo Menkeano Adservantur; cum Synonymia Critica et Novarum Specierum Diagnosibus. Published by the author. (In Latin)

Möricke, W. 1896. Versteinerungen der Tertiärformationen von Chile. Neues Jahrbuch für Mineralogie, Geologie und Paläontologie, Beilage Band, 10:548612. (In German)

Nielsen, S.N. 2013. A new Pliocene mollusk fauna from Mejillones, northern Chile. Paläontologische Zeitschrift, 87:33-66. (In German)

Osorio, C. 2012. Nueva especie del género Liotia (Gastropoda: Trochoidea: Liotiidae) del Pacífico sur orien- 
tal, norte de Chile. Revista de Biología Marina y Oceanografía, 47:407-411. (In Spanish)

Philippi, R.A. 1887. Die tertiären und quartären Versteinerungen Chiles. F.A. Brockhaus, Leipzig. (In German)

Potiez, V. and Michaud, A. 1835-1844. Galerie des mollusques, ou catalogue methodique, descriptif et raisonne des mollusques et coquilles du Museum de Douai. Vol. 1:1-560 (1838); Vol. 2:1-307 (1844); Vol. 3 (atlas):1-56 and p. 1-70 (1835-1839). (In French)

Reid, D.G. 1989. The comparative morphology, phylogeny and evolution of the gastropod family Littorinidae. Philosophical Transactions of the Royal Society of London, Series B, 324:1-110.

Reid, D.G. 1999a. The genus Littoraria Griffith and Pidgeon, 1834 (Gastropoda: Littorinidae) in the tropical eastern Pacific. Veliger, 42:21-53.

Reid, D.G. 1999b. The phylogeny of Littoraria (Gastropoda: Littorinidae): an example of the practice and application of cladistic analysis. Phuket Marine Biological Center Special Publication, 19:283-322.

Reid, D.G. 2002. The genus Nodilittorina von Martens, 1897 (Gastropoda: Littorinidae) in the eastern Pacific Ocean, with a discussion of biogeographic provinces of the rocky-shore fauna. Veliger, 45:85-169.

Reid, D.G. 2007. The genus Echinolittorina Habe, 1956 (Gastropoda: Littorinidae) in the Indo-West Pacific Ocean. Zootaxa, 1420:1-161.

Reid, D.G. 2009. The genus Echinolittorina Habe, 1956 (Gastropoda: Littorinidae) in the western Atlantic Ocean. Zootaxa, 2184:1-103.
Reid, D.G. 2011. The genus Echinolittorina Habe, 1956 (Gastropoda: Littorinidae) in the eastern Atlantic Ocean. Zootaxa, 2974:1-65.

Reid, D.G., Dyal, P., and Williams, S.T. 2010. Global diversification of mangrove fauna: a molecular phylogeny of Littoraria (Gastropoda: Littorinidae). Molecular Phylogenetics and Evolution, 55:185-201.

Reid, D.G., Dyal, P., and Williams, S.T. 2012. A global molecular phylogeny of 147 periwinkle species (Gastropoda, Littorininae). Zoologica Scripta, 41:125-136.

Rivadeneira, M.M. and Carmona, E.R. 2008. A late Pleistocene macrobenthic assemblage in Caleta Patillos, northern Chile: paleoecological and paleobiogeographical interpretations. Revista Geologica de Chile, 35(1):163-173.

Rosewater, J. 1970. The family Littorinidae in the IndoPacific. I. The subfamily Littorininae. Indo Pacific Mollusca, 2:417-506.

Sowerby, I, G.B. 1832. The Genera of Recent and Fossil Shells. Part 37. London.

Vermeij, G.J. 1973. Morphological patterns in high-intertidal gastropods: adaptive strategies and their limitations. Marine Biology, 20:319-346.

Williams, S.T. and Reid, D.G. 2004. Speciation and diversity on tropical rocky shores: a global phylogeny of snails of the genus Echinolittorina. Evolution, 58:2227-2251.

Wood, W. 1828. Supplement to the Index Testaceologicus. Wood, London.

Yeap, K.L., Black, R., and Johnson, M.S. 2001.The complexity of phenotypic plasticity in the intertidal snail Nodilittorina australis. Biological Journal of the Linnean Society, 72:63-76. 